\title{
Pentingnya Materi Lingkungan dalam Pembelajaran Bahasa Indonesia
}

Puja Andrilla/18016121

Pujaandrilla49@gmail.com

Bahasa adalah hal utama yang digunakan oleh manusia untuk mencapai tujuan serta keinginan yang telah direncakan khususnya di bidang pendidikan. Bahasa dapat disampaikan melalui lisan ataupun tulisan. Bahasa sangat berkaitan dengan siswa di sekolah. Sikap seorang siswa yang baik dapat tercermin dari tindak tutur bahasanya, buku bacaan favorit serta ungkapan yang ditulis dengan kata-kata. Sependapat dengan Thahar ( dalam Ramadhan et al 2018) mengungkapkan secara tidak sadar, seseorang telah memperoleh banyak pengetahuan, pengalaman, kaca banding, dan bahkan ilmu dari hasil bacaannya.

Kemampuan menulis seorang siswa tergantung pada bahasa yang digunakannya. Bahasa yang dituangkan melalui tulisan dipengaruhi oleh lingkungan siswa tersebut. Menulis merupakan suatu kegiatan yang sulit bagi siswa, dipersulit dengan tambahan opsi pengunaan bahasa yang harus tepat dan benar. Menurut Sukma et al (2015) hal yang dapat dilakukan untuk melibatkan siswa dalam mencari sumber dalam menulis adalah dengan memfasilitasi siswa untuk berinteraksi dengan lingkungan, sehingga siswa secara aktif dapat berpartisipasi dalam menjaga lingkungan. Kegiatan menulis secara tidak langsung dapat menguras isi kepala bagi siswa. Hal ini dikarenakan lingkungan belajar serta lingkungan sehari-hari siswa yang tidak mendukung siswa untuk berfikir terbuka.

Menurut Sukma et al (2020) tujuan pendidikan lingkungan adalah untuk memberikan pandangan positif kepada siswa mengenai cara menyikapi lingkungan dengan baik, serta menambah pengetahuan akan alam. Dengan adanya materi lingkungan pikiran serta kepedulian siswa akan lingkungan akan lebih meningkat. Penerapan materi lingkungan memberi banyak manfaat bagi siswa dan lingkungan sekitar siswa. Nkwetisma (dalam Ramadhan et al, 2019) juga mengungkapkan bahwa pendidikan lingkungan adalah upaya bersama secara sadar diselenggarakan untuk mengajar atau menarik perhatian manusia tentang bagaimana fungsi lingkungan alami dan bagaimana fungsi lingkungan alami dan bagaimana ini dapat mengelola dan melindungi alam itu. 
Cara yang efektif untuk memudahkan siswa dalam menulis yaitu dengan menerapkan materi lingkungan pada pembelajaran Bahasa Indonesia di sekolah. Menurut Ramadhan et al, (2018) penggunaan pendekatan lingkungan dalam pembelajaran menulis terbukti dalam meningkatkan keterampilan menulis siswa. Penerapan materi lingkungan pada pembelajaran Bahasa Indonesia dapat membuat siswa memahami lingkungan sekitarnya. Kegiatan memahami dan mengamati lingkungan dapat membuat siswa berfikir sehingga memunculkan ide-ide yang dituangkan dengan tulisan. Guru faktor penting untuk meningkatkan kemauan dan motivasi siswa untuk semangat dalam pembelajaran menulis. Sependapat dengan pernyataan Sukma (2013) yang menyatakan bahwa guru dan dosen memiliki peran penting dalam upaya inovatif dalam pembelajaran.

Menurut Ramadhan (2019) pendidikan lingkungan dapat membantu siswa memikirkan kembali hubungan antara manusia dan lingkungan, memahami lingkungan, menyadari masalah lingkungan, dan mempertimbangkan masalah lingkungan yang berkaitan dengan kehidupan. Materi lingkungan secara tidak langsung dapat menuntun siswa untuk memikirkan serta mengamati lingkungan sekitar mereka. Kesadaran akan lingkungan dapat menyadarkan siswa akan kepedulian terhadap lingkungan sekitar. Materi lingkungan yang diterapkan dalam pembelajaran bahasa Indonesia diprediksi memberikan manfaat yang besar bagi kedua sisi, bagi siswa dan lingkungan.

Materi lingkungan tidak hanya memberikan dampak pada akademik siswa tetapi juga merubah sikap dan keprbadian siswa. Hal ini juga didukung oleh pendapat Erdogan, Wang, Uyar, Yumusak, dan Akman (dalam Ramadan et al,2019) menyatakan bahwa dibutuhkan pengembangan individu yang sadar dan bertanggung jawab terhadap lingkungan untuk mengatasi hal ini sehingga masalah lingkungan yang berkelanjutan dan kualitas hidup yang lebih baik. Semua akan terwujud jika materi lingkungan dapat diterapkan pada pembelajaran di sekolah terkhusus pada mata pelajaran bahasa Indonesia.

Materi lingkungan dalam pembelajaran bahasa Indonesia sangat bermanfaat, khususnya untuk meningkatkan kemampuan menulis siswa. Menurut Sukma et al (2017) faktanya belajar dan menulis belum mampu meningkatkan karakter siswa hal ini karena latar belakang siswa yang berbeda-beda Pentingnya materi lingkungan berkaitan dengan pembelajaran serta lingkungan siswa. Didukung oleh pendapat Lacobs G M and Cates (dalam Ramadhan et al, 
(2019) mengungkapkan bahwa pendidikan lingkungan adalah untuk membuat siswa berpartisipasi dalam melindungi lingkungan. Guru memiliki peran penting untuk menumbuhkan kesadaran siswa akan lingkungan dengan memberikan dan menjelaskan materi tentang lingkungan.

Penerapan materi lingkungan dalam pembelajaran harus berorientasi pada siswa. Sependapat dengan itu Sutopo (dalam Sukma) mengungkapkan pembelajaran yang berorientasi pada siswa memiliki ciri-ciri yaitu: (1) menempatkan siswa sebagai subjek pembelajaran yang harus aktif mengembangkan drinya, (2) pembelajaran bersifat aktif, partisipatif, dan kolaboratifs serta secara menyeluruh memadukan aspek kecakpan hidup spesifik dan generic, (3) guru berfungsi sebagai fasilitator dan manajer pembelajaran, (4) sesuai prinsip belajar tuntas dan pengembangan bakat, setiap .peserta didik harus diberi kesempatan untuk mencapai tujuan sesuai kemampuan dan kecepatan belajarnya, (5) penilaian dilakukan secara menyeluruh, menyangkut hasil dan proses pembelajaran. Pembelajaran seperti ini dapat membantu siswa lebih mudah menyerap dan memahami materi lingkungan dalam pembelajaran.

Berdasarkan angket yang penulis sebarkan mengenai “ Pentingnya Materi Lingkungan dalam Pembelajaran Bahasa Indonesia” kepada mahasiswa Universitas Negeri Padang semester 1 dan semester 5, mahasiswa Politeknik Negeri Padang semester 5, mahasiswa Universitas Riau semester 5, mahasiswa STKIP Farmasi, pelajar, wirausaha dan ibu rumah tangga. Dari jumlah keseluruhan 37 responden yang ikut serta mengisi angket tersebut lebih dominan perempuan 27 responden dan laki-laki 10 responden dengan persentasi 73\% perempuan, 27\% laki-laki. Pernyataan pertama "Materi lingkungan dalam pembelajaran bahasa Indonesia memberi dampak positif kepada siswa" 64,9\% menyatakan sangat setuju, 35,1 menyatakan setuju, 0\% menyatakan kurang setuju dan 0\% menyatakan tidak setuju. Pernyataan kedua "Materi lingkungan dalam pembelajaran bahasa Indonesia sangat berguna untuk mengatasi kesulitan siswa dalam belajar" $56,8 \%$ menyatakan setuju, 35,1\% menyatakan sangat setuju, 8,1\% menyatakan kurang setuju dan 0\% menyatakan tidak setuju. Pernyataan ketiga "Membersihkan kelas sebelum proses pembelajaran dilakukan, agar siswa lebih konsentrasi dan nyaman saat belajar. Merupakan salah satu materi pembelajaran lingkungan yang secara tidak langsung telah dilakukan siswa" 48,6\% menyatakan sangat setuju, 48,6 menyatakan setuju, 2,8\% menyatakan kurang setuju dan 0\% tidak setuju. Pernyataan Keempat "Peran orang tua sangat penting untuk membimbing siswa 
untuk memahami dan mengamalkan materi pembelajaran tentang lingkungan" 48,6\% menyatakan sangat setuju, 45,9\% menyatakan setuju, 5,4\% menyatakan kurang setuju dan $0 \%$ menyatakan tidak setuju. Pernyataan kelima "Materi lingkungan berkaitan erat dengan pembelajaran bahasa Indonesia" 62,2\% menyatakan setuju, 35,1\% menyatakan sangat setuju, 2,7\% menyatakan kurang setuju dan $0 \%$ menyatakan tidak setuju. Pernyataan keeenam "Materi lingkungan dapat menjadikan siswa mengamati lingkungan sekitarnya serta mengkaitkannya dengan pembelajaran bahasa Indonesia" 70,3\% menyatakan setuju dan 29,7\% menyatakan sangat setuju, 0\% menyatakan kurang setuju dan 0\% menyatakan tidak setuju. Pernyataan ketujuh "Dalam pembelajaran bahasa Indonesia siswa mampu melihat perubahan yang terjadi pada diri siswa sebelum dan setelah mempelajari materi lingkungan" 64,9\% menyatakan setuju, $32,4 \%$ menyatakan sangat setuju, 2,7\% menyatakan kurang setuju dan $0 \%$ menyatakan tidak setuju. Pernyataan kedelapan "Materi lingkungan dapat dijadikan media oleh guru dalam pembelajaran bahasa Indonesia" 59,5\% menyatakan sangat setuju, 37,8\% menyatakan setuju, 2,7\% menyatakan kurang setuju dan $0 \%$ menyatakan tidak setuju. Pernyataan kesembilan "Materi lingkungan dalam pembelajaran bahasa Indonesia dapat mengubah pola pikir siswa tentang lingkungan" 51,4\% menyatakan setuju, 45,9\% menyatakan sangat setuju, 2,7\% menyatakan kurang setuju dan $0 \%$ menyatakan tidak setuju. Pernyataan kesepuluh "Guru harus berperan aktif untuk menjelaskan kepada siswa pentingnya materi lingkungan" 54,1\% menyatakan setuju, 45,9\% menyatakan sangat setuju, 0\% menyatakan kurang setuju dan 0\% menyatakan tidak setuju.

Berdasarkan hasil penyebaran angket yang telah dilakukan, dapat penulis simpulkan bahwa materi lingkungan dalam pendidikan memilliki peran penting untuk menyadarkan siswa akan lingkungan sekitar. Secara tidak langsung lingkungan mendukung peningkatan keterampilan siswa baik itu keterampilan menulis, keterampilan membaca, keterampilan berbicara dan keterampilan menyimak. Materi lingkungan dapat membantu siswa untuk mengatasi kesulitan saat menyelesaikan topik-topik pada pembelajaran bahasa Indonesia yang sebagian besar terdiri dari teks. Lembaga pendidikan berperan penting untuk menumbuhkan wawasan mengenai lingkungan kepada siswa serta guru berperan sebagai fasilitaor dalam proses pengembangan materi lingkungan. 


\section{DAFTAR PUSTAKA}

Ramadhan, Syahrul, Guci \& Nursaid. (2016). Korelasi penguasaan kosakata bidang lingkungan hidup dengan menulis karangan argumentasi tentang lingkungan hidup.Jurnal Pendidikan Bahasa dan Sastra Indonesia 5(2).

Ramadhan, Syahrul, Sukma \& Indriyani. (2019) Environmental education and disaster mitigation through language learning. Earth and Environmental Science 314.

Ramadhan, Syahrul. (2008) Representasi kesantunan tindak tutur berbahasa Indonesia dalam pembelajaran di kelas ( Kajian Etnografi Komunikasi). Diksi 15(2).

Ramadhan, Syahrul, Sari \& Rasyid. (2018) Hubungan antara keterampilan membaca pemahaman dengan keterampilan menulis teks laporan hasil observasi siswa kelas $X$ SMK Negeri 3 Padang. Jurnal Pendidikan Bahasa dan Sastra Indonesia, 7 (3).

Ramadhan, Syahrul, Halawa \& Gani (2018) Kesantunan Berbahasa Indonesia Dalam Tindak Tutur Melarang Dan Mengkritik Pada Tujuh Etnis.Lingua XV (2)

Ramadhan, Rozana \& Basri (2018) Kontribusi Motivasi Belajar Dan Penguasaan Kosakata Terhadap Keterampilan Menulis Teks Eksposisi Siswa Sma.Lingua XIV (1).

Sukma, Elfia. (2017). Pembelajaran sastra yang intergratif berbasis kompetensi. Jurnal UNY. International Seminars On Language And Arts (ISLA).

Sukma, Elfia., Mahyudin, Rahmatina \& Suriani. (2018) Problem In Oral Language Teaching In Primary School. Advances in Social Science, Education and Humanities Research, volume 301

Sukma, Elfia. dan Mansur Lubis. (2013). Pembelajaran menulis pantun secara integrative berbasis lesson study. Jurnal Pendidikan Bahasa dan Sastra. 14(1).

Sukma, Elfia. (2015). Peningkatan keterampilan menulis dengan model PAKEM melalui teknik menjadi wartawan junior di sekolah dasar. Jurnal Pendidikan Sains dan Kemanusiaan. $8(1)$ 


\section{LAMPIRAN \\ TABEL 1}

\section{Angket Kaitan Pembelajaran Bahasa Indonesia dengan Lingkungan}

\begin{tabular}{|r|l|c|c|c|c|}
\hline No & \multicolumn{1}{|c|}{ Pertanyaan } & SS & S & KS & TS \\
\hline 1. & $\begin{array}{l}\text { Materi lingkungan dalam pembelajaran bahasa } \\
\text { Indonesia memberi dampak positif kepada siswa. }\end{array}$ & $\mathbf{6 4 , 9 \%}$ & $\mathbf{3 5 , 1 \%}$ & - & - \\
\hline 2. & $\begin{array}{l}\text { Materi lingkungan dalam pembelajaran bahasa } \\
\text { Indonesia sangat berguna untuk mengatasi kesulitan } \\
\text { siswa dalam belajar. }\end{array}$ & $\mathbf{3 5 , 1 \%}$ & $\mathbf{5 6 , 8 \%}$ & $\mathbf{8 , 1 \%}$ & - \\
\hline 3. & $\begin{array}{l}\text { Membersihkan kelas sebelum proses pembelajaran } \\
\text { dilakukan, agar siswa lebih konsentrasi dan nyaman } \\
\text { saat belajar. Merupakan salah satu materi } \\
\text { pembelajaran lingkungan yang secara tidak } \\
\text { langsung telah dilakukan siswa. }\end{array}$ & $\mathbf{4 8 , 6}$ & $\mathbf{4 8 , 6 \%}$ & $\mathbf{2 , 8 \%}$ & - \\
\hline $\mathbf{4 .}$ & $\begin{array}{l}\text { Peran orang tua sangat penting untuk membimbing } \\
\text { siswa untuk memahami dan mengamalkan materi } \\
\text { pembelajaran tentang lingkungan. }\end{array}$ & $\mathbf{4 8 , 6 \%}$ & $\mathbf{4 5 , 9 \%}$ & $\mathbf{5 , 4 \%}$ & - \\
\hline $\mathbf{5 .}$ & $\begin{array}{l}\text { Materi lingkungan berkaitan erat dengan } \\
\text { pembelajaran bahasa Indonesia. }\end{array}$ & $\mathbf{3 5 , 1 \%}$ & $\mathbf{6 2 , 2 \%}$ & $\mathbf{2 , 7 \%}$ & - \\
\hline $\mathbf{6 .}$ & $\begin{array}{l}\text { Materi lingkungan dapat menjadikan siswa } \\
\text { mengamati lingkungan sekitarnya serta } \\
\text { mengaitkannya dengan pembelajaran bahasa } \\
\text { Indonesia }\end{array}$ & $\mathbf{2 9 , 7 \%}$ & $\mathbf{7 0 , 3 \%}$ & - & - \\
\hline 7. & $\begin{array}{l}\text { Dalam pembelajaran bahasa Indonesia siswa mampu } \\
\text { melihat perubahan yang terjadi pada diri siswa } \\
\text { sebelum dan setelah mempelajari materi lingkungan. }\end{array}$ & $\mathbf{3 2 , 4 \%}$ & $\mathbf{6 4 , 9 \%}$ & $\mathbf{2 , 7 \%}$ & - \\
\hline $\mathbf{8 .}$ & $\begin{array}{l}\text { Materi lingkungan dapat dijadikan media oleh guru } \\
\text { dalam pembelajaran bahasa Indonesia }\end{array}$ & $\mathbf{5 9 , 5 \%}$ & $\mathbf{3 7 , 8 \%}$ & $\mathbf{2 , 7 \%}$ & - \\
\hline $\mathbf{9 .}$ & $\begin{array}{l}\text { Materi lingkungan dalam pembelajaran bahasa } \\
\text { Indonesia dapat mengubah pola pikir siswa tentang } \\
\text { lingkungan. }\end{array}$ & $\mathbf{4 5 , 9 \%}$ & $\mathbf{5 1 , 4 \%}$ & $\mathbf{2 , 7 \%}$ & - \\
\hline $\mathbf{1 0}$ & $\begin{array}{l}\text { Guru harus berperan aktif untuk menjelaskan } \\
\text { kepada siswa pentingnya materi lingkungan. }\end{array}$ & $\mathbf{4 5 , 9 \%}$ & $\mathbf{5 4 , 1 \%}$ & - & - \\
\hline
\end{tabular}

Jumlah responden adalah 37 orang yang terdiri dari Mahasiswa Universitas Negeri Padang, Mahasiswa Politeknik Negeri Padang, Mahasiswa Universitas Riau, Mahasiswa STKIP Farmasi, Pelajar SMK Negeri 2 Pariaman, Wirausaha dan Ibu Rumah Tangga.

\section{Keterangan :}

SS : Sangat Setuju 

S : Setuju
KS : Kurang Setuju
TS : Tidak Setuju 